\title{
Possibility of obtaining wastewater heat from a sewage treatment plant by the means of a heat pump - a case study
}

\author{
Stawomir Pochwała ${ }^{1, *}$, and Paulina Kotas ${ }^{2}$ \\ ${ }^{1}$ Department of Mechanical Engineering, Opole University of Technology, Mikołajczyka 5, \\ 45-271 Opole, Poland \\ ${ }^{2}$ AGH University of Science and Technology, Department of Environmental Engineering and Mineral \\ Processing, 30-059 Krakow, Poland
}

\begin{abstract}
The research was carried out in the mechanical and biological wastewater treatment plant of the city of Prószków in Poland. There is a demand for heat for hot tap water, heating and technological purposes. There is no gas network in the town, therefore it is necessary either to install solid fuel boiler or electrical equipment to generate heat. Instead, a system based on a heat pump (HP) was proposed, which is a pro-ecological and proeconomical alternative. The research involved the measurements necessary to develop energy balances and collection of local climate data. As a result, possible heat from sewage was determined for an exemplary heating season. For the assumed calculation conditions, the maximum amount of heat is $346 \mathrm{~kW}$ of which $98 \%$ will be used for heating up the sequential biological reactor (SBR) and $2 \%$ will be used for social needs. The current SBR temperature in the winter period is $8^{\circ} \mathrm{C}$, which significantly limits the process of biological treatment. The optimum temperature range of sewage in SBR is $15-25^{\circ} \mathrm{C}$. Based on the collected data, the concept of a HP-based system for generating heat was developed to maintain the optimum temperature. Sewage is a very effective heat source for the HP. This ensures the highest coefficient of performance (COP).
\end{abstract}

\section{Introduction}

A large generation of waste energy per capita, classifies waste management (WM) as one of the core issues in sustainable development of EU regions [1]. Wastewater is an important source of energy [2]. One of the possibilities and necessities in sustainable development is recovering this energy in the form of heat from waste sources. The energy contained in sewage is often neglected part of energy losses in residential buildings, yet it is not used and goes to sewage systems. It is estimated that we have to consume up to $20 \%$ of all energy used in the household for preparing domestic hot water, of which more than half of the energy is lost in wastewater [3].

\footnotetext{
*Corresponding author: s.pochwala@po.opole.pl,pochwala.slawomir@gmail.com
} 
The average annual sewage temperature, which varies between $30^{\circ} \mathrm{C}$ and $35^{\circ} \mathrm{C}$, is attributed to wastewater generated in households [4]. However, this is the temperature that wastewater characterizes at the time of their formation. During the flow to the sewage treatment plant, their temperature decreases significantly. This is strictly dependent on the size of the sewer system and collectors, but also the flow rate. Ultimately, the average temperature that sewage has on the inflow to the treatment plant varies between $11-12^{\circ} \mathrm{C}[5]$. This applies to all sewage, such as gray sewage, i.e. generated during the use of showers, bathtubs, washing machines as well as municipal and industrial sewage. Therefore, heat exchangers and heat pumps are an indispensable element of a heat recovery systems, which allow easy collection of such waste energy.

The mechanism for converting this energy takes place in a multiphase systems in wastewater and in a systems inside the HP. Currently, many studies are carried out to increase the efficiency of these processes and intensify the collection of heat from heat exchangers [12-15].

In the presented work, the authors show the possibilities of obtaining heat by means of a heat pump from wastewater in the sewage treatment plant of the town of Prószków in the south-west region of Poland.

\section{Problem definition}

The key problem in the analyzed sewage treatment plant is the improvement of the reduction of biological oxygen demand (BOD), chemical oxygen demand (COD), $\mathrm{N}_{\text {org }}, \mathrm{N}_{\mathrm{NH} 4}$ and $\mathrm{P}$ indicators in the treated wastewater, which is required in the Polish legal water permit. This effect can be achieved by raising the temperature in SBR. In addition, there is a need to create heat for social services (hot tap water and space heating).

There is no gas network in the city of Prószków. This means that for the production of heat for the needs of hot tap water, space heating and technology, it is necessary to make either a solid fuel boiler or the use of electrical equipment. In the case of a boiler, there is the problem of an additional technical room in which the boiler, fuel storage space and additional full-time service related to the boiler operation will be placed. The second solution offers simple electrical heaters as well as service but at high price of electricity. In the case of heat generation from electricity, heat pumps (HP) are more effective than electrical heaters or electric furnaces.

Due to the fact that $98 \%$ of the heat demand is covered by the technology process, the most important aspect of the heat recovery system is the optimal location of the HP heat source. Incorrectly located exchanger in the technological system of the treatment plant will cause deterioration of the biological wastewater treatment process. Also, the sewage itself as a multiphase medium can generate problems in the operation of the exchanger and, as a result, limit the heat exchange process [16].

\section{Measurement setup}

Figure 1 presents the diagram of the technological process sequence carried out in the tested mechanical and biological sewage treatment plant. 


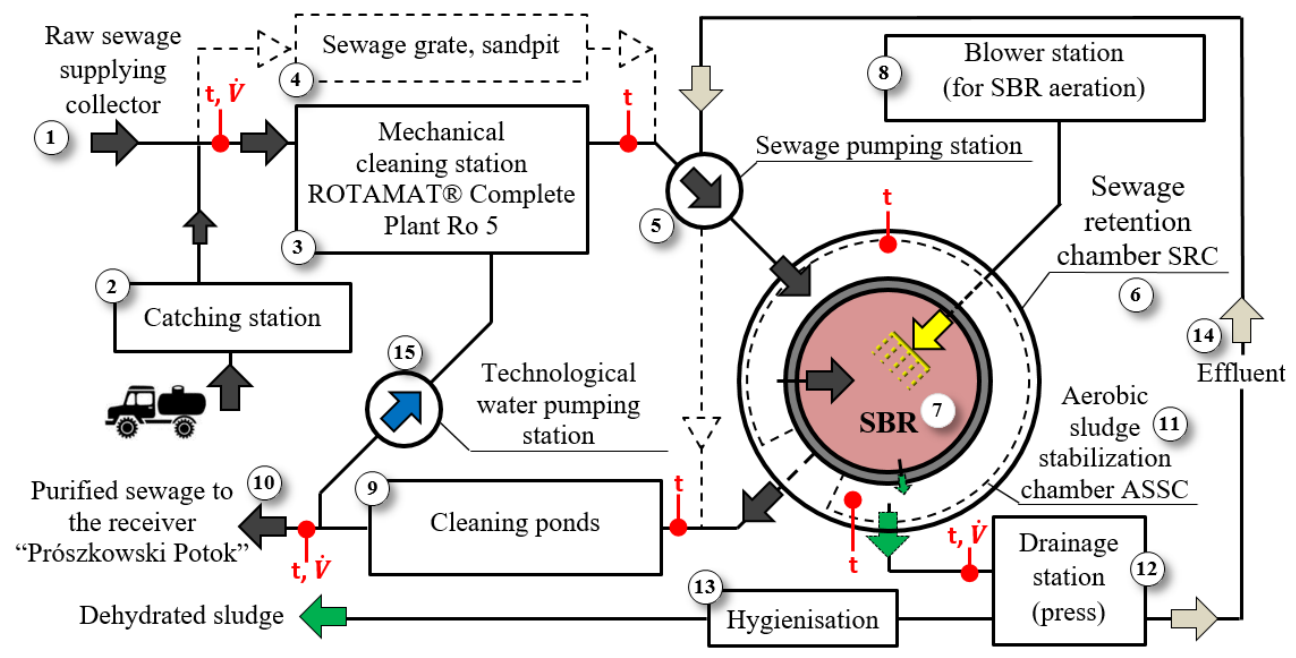

Fig. 1. Technological diagram of the Prószków sewage treatment plant with measurement locations.

The characteristics of wastewater treatment processes are as follows according to Figure 1:

1. Gravitational inflow of sewage ( $0.3 \mathrm{~m}$ diameter collector).

2. Slurry tankers sewage discharge station.

3. Mechanical cleaning station (sandpit and grate).

4. Mechanical back-up cleaning - hand-held grate and sandpit, also a sewage buffer tank.

5. Mechanical treated sewage pumping station into the sewage retention chamber (SRC).

6. SRC is a part of a SBR (the volume of SRC is $246.5 \mathrm{~m}^{3}$ )

7. SBR operates in 8 hour work cycles and during this time accumulation of incoming sewage amount finally reaches $148 \mathrm{~m}^{3}$. Biological treatment in SBR consists of subsequent stages: filling, aeration, anaerobic mixing, clarification, clean-up effluent.

8. Compressor station for aeration of wastewater of SBR.

9. Cleaning ponds - wastewater conditioning and discharge to the receiver (cleaning of suspended matter, phosphorus and nitrogen compounds).

10. Draining of treated wastewater to the receiver ditch, through measuring wells to the "Prószkowski Potok" natural brook.

11. Excess sludge to the Aerobic Sludge Stabilization Chamber (ASSC).

12. Mechanical sludge dewatering on a belt press.

13. Hygienisation and transfer of dehydrated and stagnant sludge for agricultural use.

14. Effluent from press is returned to the pumping station and mixed with mechanically treated sewage.

15. Technological pumping station - purified wastewater for the plant equipment cleaning.

\section{Results}

The result of the work is the concept of a system used to generate heat for the needs of hot tap water, space heating for a social-laboratory building and technology processing heat based on a heat pump (HP). The following information was collected and recorded for the preparation of balances and studies: climatic data for the city of Prószków, incoming raw sewage flux, excess sediment flow, sewage well temperature, grate temperature, SBR temperature, excess silt precipitate from ASSC, hot water consumption, number of employees and indoor temperature in the building. 
The HP heat source heat exchanger is located in the wastewater. To determine the power of the HP and the size of the exchanger, the heat demand for individual targets and heat recoverable from wastewater was determined. Thermal needs were determined at the level of:

- The heat demand $\left(Q_{H, n d}\right)$ for heating the social and laboratory building with an area of $40 \mathrm{~m}^{2}$ was estimated at $4849.7 \mathrm{kWh} / \mathrm{a}$. However peak demand for heating power, $\dot{Q}_{h_{-} \max c h}=4.8 \mathrm{~kW}$. Momentary heating power demand is determined from equation (1).

where:

$$
\dot{Q}_{h_{-} c h}(\tau)=\dot{Q}_{h_{-} \max c h} \frac{t_{\text {in }}-t_{\text {out }}(\tau)}{t_{\text {in }}-t_{\text {out }} \text { min }}
$$

$$
\begin{array}{ll}
t_{\text {in }} & - \text { required internal temperature, } \\
t_{\text {out }}(\tau) & - \text { instantaneous outside temperature, } \\
t_{\text {out_min }} & - \text { computational outside temperature (zone } 3 \text { in Poland } t_{\text {out } \_ \text {min }}=-20^{\circ} \mathrm{C} \text { ). }
\end{array}
$$

- Average heating power $\dot{Q}_{h_{-} m h t w}$ for the hot tap water was estimated at the $0.4 \mathrm{~kW}$ level.

- Unit heating power demand for technology, $\dot{Q}_{h_{-} t u}$ in the SRC, was estimated at $21.53 \mathrm{~kW}$ (for heating $148 \mathrm{~m}^{3}$ of sewage by $1^{\circ} \mathrm{C}$ ).
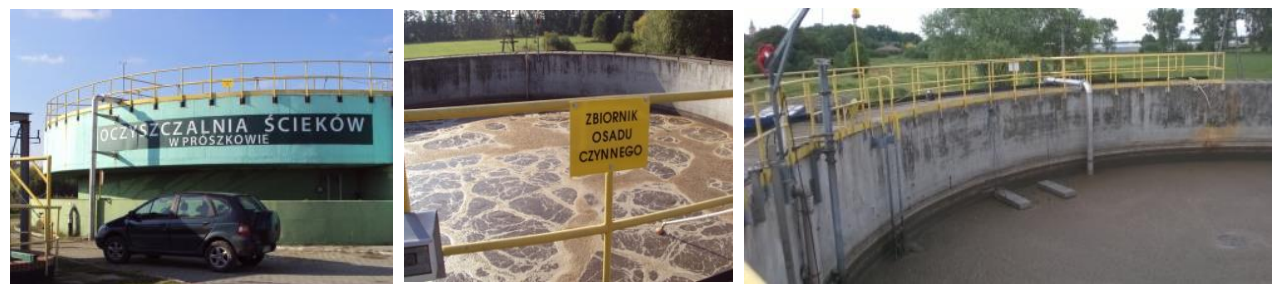

Fig. 2. View of the sequential biological reactor (SBR) of the sewage treatment plant in Prószków.

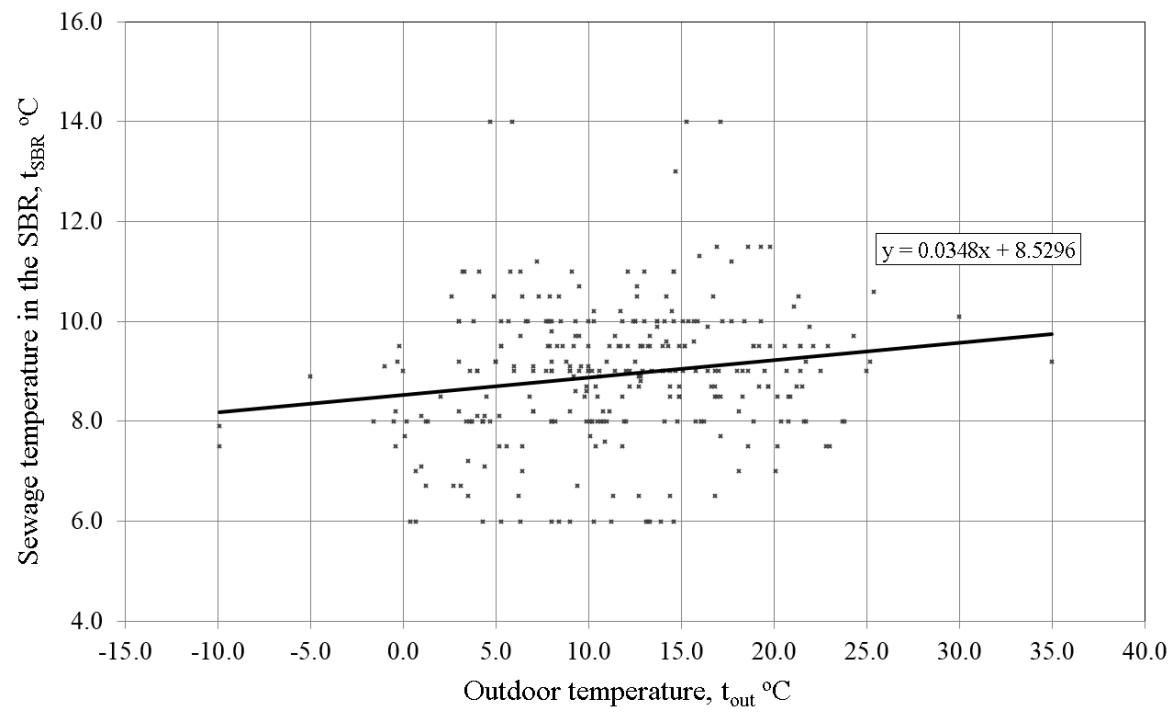

Fig. 3. Temperature dependence of sewage in the SBR and the outside temperature, based on climatic data and sewage temperature measurements in the SBR.

In the SBR reactors (Figure 2), there is a close relationship between the effectiveness of biogen removal and the temperature of the treated wastewater $[3,18]$. In Polish legislation, 
the minimum temperature for the nitrification process is $12^{\circ} \mathrm{C}$ [20]. For the biological wastewater treatment process, it is also important to limit temperature fluctuations and keep it constant [21]. The optimum temperature of sewage in the SBR should be $15-25^{\circ} \mathrm{C} \mathrm{[22].}$

Equation (2) was derived from the data shown in Figure 3 and represents the dependence of the sewage temperature in the $\operatorname{SBR}\left(t_{S B R}\right)$ to the outdoor air temperature $\left(t_{\text {out }}(\tau)\right)$.

$$
t_{S B R}=0.0348 \cdot t_{\text {out }}(\tau)+8.5296
$$

Initially in the case of $t_{\text {out } \min }=-20^{\circ} \mathrm{C}$ the sewage in SBR has a temperature of $t_{S B R}=7.9^{\circ} \mathrm{C}$. This means that the sewage needs to be heated to reach the optimum temperature range by a $7.1-17.1^{\circ} \mathrm{C}$. For this purpose the technological thermal power $\dot{Q}_{h_{-} t}$ is needed in the range of $152.9-368.2 \mathrm{~kW}$. Total peak heating power demand $\dot{Q}_{h_{-} t o t a l}$ for heating, hot tap water and technology is in the range of $157.7-373.0 \mathrm{~kW}$.

In order to maintain the limits of biochemical indicators from the Polish water permit, the appropriate temperature in SBR should be reached. Currently, there are significant overshoots which means the need to use a higher temperature in the reactor. For this purpose, it was proposed to obtain heat from the following places:

a) Raw sewage in the collecting well, (Figure $4 \mathrm{a}$, and $\dot{Q}_{h_{-} 1}$ in Table 1),

b) Aerobic sludge stabilization chamber (ASSC), (Figure $4 \mathrm{~b}$, and $\dot{Q}_{h_{-} 2}$ in Table 1)

c) Cleaning ponds, $\dot{Q}_{h_{-} 3}$ (Figure $4 \mathrm{c}$, and Table 1)

a)
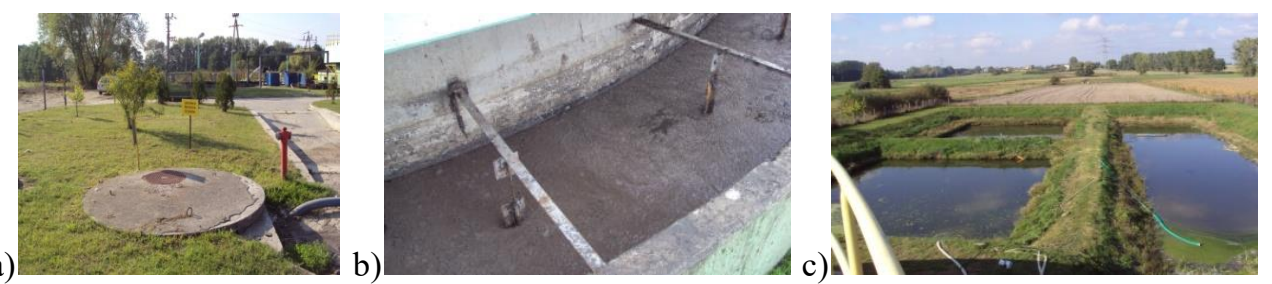

Fig. 4. View of the possible heat recovery locations: a) collecting well, b) ASSC, c) cleaning ponds.

In the first location (Figure 4a), due to the fact that the raw sewage cools down in the mechanical part, the optimal solution is to cool them to the limit temperature. The limit temperature value of raw wastewater was determined at $3{ }^{\circ} \mathrm{C}$. In this solution, the maximum thermal power that can be obtained is $209.6 \mathrm{~kW}$, which can be used to heat the sewage by $9.7^{\circ} \mathrm{C}$, and the temperature in the reactor is set at $16.8^{\circ} \mathrm{C}$. In this way, heat losses will be limited and at this temperature the wastewater does not freeze before reaching the reactor retention tank.

The second location is the aerobic sludge stabilization chamber (ASSC) (Figure 4b), with a volume of $575 \mathrm{~m}^{3}$, which surrounds the main chamber of the SBR. Due to the fact that this chamber is open and exposed to direct external conditions, there are large heat losses. The average flow rate of the hydrated excess sludge in the analyzed period was $23.5 \mathrm{~m}^{3} / \mathrm{d}$. With the existing system, for an outdoor air temperature $t_{\text {out }} \leq-11.4^{\circ} \mathrm{C}$, the temperature of the hydrated sludge drops below $4^{\circ} \mathrm{C}$ and it is not possible to recover the heat. When the outdoor temperature is higher than the temperature of the sewage in SBR then there are heat gains from the surroundings into the ASSC. For the highest ambient temperature observed in the tests $\left(t_{\text {out }}=35.5^{\circ} \mathrm{C}\right)$, the possible thermal power recovering is up to $7.8 \mathrm{~kW}$. If supplied sewage is heated before entering the SBR and the ASSC is insulated then, for example, at $t_{\text {out }}=-20^{\circ} \mathrm{C}$ and $t_{S B R}=16.8^{\circ} \mathrm{C}$ it will be possible to obtain $11.2 \mathrm{~kW}$ of thermal power. Another example is for $t_{\text {out }}=35.5^{\circ} \mathrm{C}$ and $t_{S B R}=16.8^{\circ} \mathrm{C}$, recovered thermal power is up to $15.8 \mathrm{~kW}$. 
The third location is the cleaning ponds (Figure 4c), with a volume of $1441 \mathrm{~m}^{3}$ and a total area of $1320 \mathrm{~m}^{2}$. The average sewage flow rate through the ponds in the analyzed period was $448.6 \mathrm{~m}^{3} / \mathrm{d}$. Due to the large surface area of contact with the environment, the greatest instabilities of the heat losses and gains occur here. With the existing system, for an outdoor air temperature $t_{\text {out }} \leq-10.0^{\circ} \mathrm{C}$, the temperature of the treated wastewater drops below $4^{\circ} \mathrm{C}$ and the heat losses are so high that it is not possible to recover the heat. However at high outdoor air temperatures and high solar irradiation, for example at $t_{\text {out }}=35.5^{\circ} \mathrm{C}$, the thermal power to be recovered is up to $270.8 \mathrm{~kW}$. If supplied sewage is heated before entering the SBR, for example, at $t_{\text {out }}=-18.1^{\circ} \mathrm{C}$ and $t_{S B R}=16.8^{\circ} \mathrm{C}$ it will be possible to obtain $2.1 \mathrm{~kW}$ of thermal power. Another example is for $t_{\text {out }}=35.5^{\circ} \mathrm{C}$ and $t_{S B R}=16.8^{\circ} \mathrm{C}$, recovered thermal power is up to $424.2 \mathrm{~kW}$.

Table 1. Obtainable thermal power for $t_{\text {out } \_ \text {min }}$, along with theoretically assumed temperature in the SBR and the real maximum temperature that can be achieved with the use of the recovered heat.

\begin{tabular}{|c|c|c|c|c|c|}
\hline $\begin{array}{c}\text { Theoretical SBR } \\
\text { Temp. }\end{array}$ & $\dot{\boldsymbol{Q}}_{\boldsymbol{h}_{-} \mathbf{1}}$ & $\dot{\boldsymbol{Q}}_{\boldsymbol{h}_{-} \mathbf{2}}$ & $\dot{\boldsymbol{Q}}_{\boldsymbol{h}_{-} \mathbf{3}}$ & $\dot{\boldsymbol{Q}}_{\boldsymbol{h}_{-} \text {total }}$ & $\begin{array}{c}\text { Real SBR } \\
\text { Temp. }\end{array}$ \\
\hline${ }^{\circ} \mathbf{C}$ & $\mathbf{k W}$ & $\mathbf{k W}$ & $\mathbf{k W}$ & $\mathbf{k W}$ & ${ }^{\circ} \mathbf{C}$ \\
\hline 15 & 209.6 & 9.1 & -101.5 & 218.7 & 18.1 \\
\hline 16 & 209.6 & 10.3 & -79.7 & 219.9 & 18.1 \\
\hline 17 & 209.6 & 11.4 & -57.9 & 221.0 & 18.2 \\
\hline 18 & 209.6 & 12.5 & -36.2 & 222.1 & 18.2 \\
\hline 19 & 209.6 & 13.7 & -14.4 & 223.3 & 18.3 \\
\hline 20 & 209.6 & 14.8 & 7.3 & 231.7 & 18.7 \\
\hline 21 & 209.6 & 16.0 & 29.1 & 254.6 & 19.7 \\
\hline 22 & 209.6 & 17.1 & 50.8 & 277.5 & 20.8 \\
\hline 23 & 209.6 & 18.2 & 72.6 & 300.4 & 21.9 \\
\hline 24 & 209.6 & 19.4 & 94.3 & 323.3 & 22.9 \\
\hline 25 & 209.6 & 20.5 & 116.1 & 346.2 & 24.0 \\
\hline
\end{tabular}

Each of the locations of discussed heat recovery points requires the use of a different heat exchanger design. In the case of heat recovery from the sewage collecting well (Figure 4a), it is a good to choose a system with a TubeWin HUBER heat exchanger. This device does not require a large space for installation, directly directing pre-treated wastewater to the compact heat exchanger RoWin [23]. Another solution is the various types of inserts or claddings submerged into the sewerage collector, and the required efficiency is achieved by increasing the contact surface $[24,25]$.

The heat recovery from the ASSC (Figure 4b) requires, due to the hydrated sediment, a special construction resistant to strong muddy pollution. In this case, a membrane collector, made of flexible membrane exchangers can be used [26].

The simplest and the cheapest solution can be used in the case of cleaning ponds (Figure $4 \mathrm{c}$ ). In this case, the exchanger is in the form of coils made of polyethylene pipes arranged on the bottom of ponds, filled with an aqueous glycol solution and laden with prefabricated concrete elements [27].

Depending on the process requirements in the discussed solution, the heat obtained from the indicated places will be transferred to the heat sink. The optimal heat sink is SRC to which the heat will be delivered by means of a HP. Heat will be transferred to the SRC by heat exchanger made of PE pipe coils mounted on racks fixed inside SRC walls [28]. In addition, a similar structure can be placed in the SBR for temperature stabilization. Its operation is particularly efficient due to the use of aeration, which significantly intensifies heat exchange. Additionally, it is necessary to insulate the SBR together with the SRC and ASSC as well as possible. Because the reservoir is entirely located above the surface, and its construction is made of reinforced concrete walls with a thickness of $0.2 \mathrm{~m}$, it is exposed to atmospheric 
conditions. In the case of concrete walls, it is enough to use any technology of insulation systems. To minimize heat losses from the reactor, it should also be covered and insulated from above. For this purpose, it is possible to use special containment dome, which will additionally reduce the emission of unpleasant odors from the SBR [29].

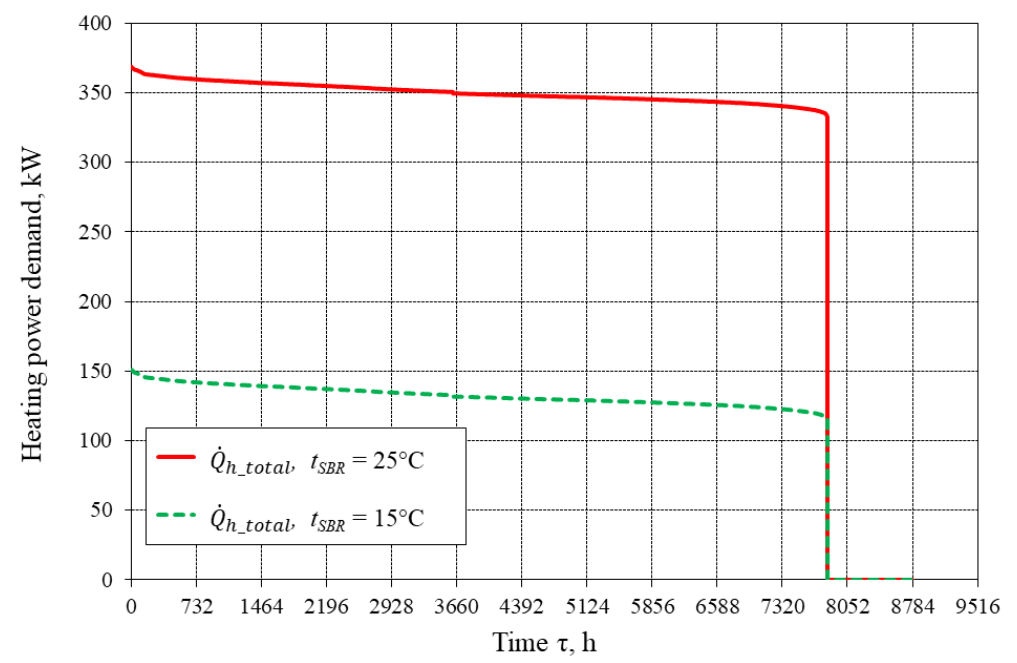

Fig. 5. Ordered chart of total thermal power demand for temperature limits in SBR.

As a result of the measurements and calculations carried out, the total annual heating power demand was determined for technological and social-living purposes. For the analyzed period, the hourly outdoor temperatures were in the range of $-9.9-35.5^{\circ} \mathrm{C}$. The Figure 5 shows the ordered chart of total demand of thermal power for temperature limits in SBR $\left(15-25^{\circ} \mathrm{C}\right)$. On this basis, the selection of HP heating power should be in the range of $152-369 \mathrm{~kW}$.

\section{Conclusions}

On the basis of the conducted analysis, the possibilities of obtaining heat by means of a HP from the wastewater in a sewage treatment plant were determined. The use of a HP was justified, especially for the needs of technology, which is $98 \%$ of total heating power demand. Sewage is a very efficient source of heat for the HP. It was found that the HP heat exchanger can be placed in the raw sewage collector, ASSC or cleaning ponds. The simplest and the cheapest solution is placement the heat exchanger in the cleaning ponds. However, the highest thermal power is available from raw sewage collector. Assuming that the wastewater is cooled to $4^{\circ} \mathrm{C}$, with the computational outside air temperature of $-20^{\circ} \mathrm{C}$, the highest required HP thermal power should be included in the values of $165-380 \mathrm{~kW}$. Usage of waterwater HP for this purpose is recommended. This type of HP is characterized by high COP up to about 5.5, which gives multiple surpluses of available thermal power. The proposed solution completely meets the set goals. Good choice is HP with constant thermal power. Required thermal power can be obtained by combining the HPs in a cascade. In considered case, sewage in $\mathrm{SBR}$ should be heated not higher than $25^{\circ} \mathrm{C}$, which will improve the COP indicator.

\section{References}

1. T. Tomić, D.F. Dominković, A. Pfeifer, D.R. Schneider, A.S. Pedersen, N. Duić, Energy, 137 (2017) 
2. M. Tańczuk, W. Kostowski, M. Karaś, Energ. Convers. Manage. 125 (2016)

3. J. Górski, D. Matuszewska, Piece Przemysłowe \& Kotły, 7-8 (2013)

4. R. Błażejewski, Kanalizacja wsi (PZITS Oddział Wielkopolski, Poznań, 2003)

5. G. Kaczor, PAN, 3 (2008)

6. J.F. Wang, C. Brown, D.J. Cleland, Int. J. Refrig. 86 (2018)

7. S. Hiawen, W. Tingyu, J. Xin, R. Zhiyong, Y. Haiyang, L. Duanmu, Procedia Engineer. 146 (2016)

8. N. Qin, P.Z. Hao, Appl. Therm. Eng. 124 (2017)

9. O. Culha, H. Gunerhan, E. Biyik, O. Ekren, A. Hepbasli, Energ. Buildings, 104 (2015)

10. A. Hepbasli, E. Biyik, O. Ekren, H. Gunerhan, M. Araz, Energ. Convers. Manage. 88 (2014)

11. L. Postrioti, G. Baldinelli, F. Bianchi, G. Buitoni, F. Di Maria, F. Asdrubali, Appl. Therm. Eng. 102 (2016)

12. S. Anweiler, M. Masiukiewicz, Therm. Sci. 20, 4 (2016)

13. R. Ulbrich, M. Krótkiewicz, N. Szmolke, S. Anweiler, M. Masiukiewicz, D. Zajac, P.I. Mech. Eng. E - J Pro. 216, 4 (2002)

14. M. Masiukiewicz, R. Ulbrich, Inz. Chem. Procesowa 25, 3 (2004)

15. S. Anweiler, R. Ulbrich, Inz. Chem. Procesowa 25, 3 (2004)

16. L. Troniewski, R. Dyga, Inz. Chem. Procesowa 24, 4 (2003)

17. A. Makuch, Thesis, Wydział Chemiczny Politechniki Gdańskiej, Królewska Politechnika w Sztokholmie (2009)

18. G.A. Ekama, M.C. Wentzel, Water Sci. Technol. 39, 6 (1999)

19. P. Bugajski, Infrastruktura i ekologia terenów wiejskich, 2 (2011)

20. Dz.U. 2014 poz. 1800 - Rozporządzenie Ministra Środowiska z dnia 18 listopada 2014 r. w sprawie warunków, jakie należy spełnić przy wprowadzaniu ścieków do wód lub do ziemi, oraz w sprawie substancji szczególnie szkodliwych dla środowiska wodnego

21. N.R. Louzeiro, D.S. Mavinic, W.K. Oldham, A. Meisen, I.S. Gardnere, Water Resour. 36 (2002)

22. M. Bobrowski, Podstawy biologii sanitarnej (Wydawnictwo Ekonomia i Środowisko, Białystok, 2002)

23. http://www.huber.com.pl/pl/rozwiazania/odzysk-ciepla-ze-sciekow/scieki-zrodloenergii.html (access 01.2018)

24. https://www.brandenburger-liner.com/de/produkte-leistungen/bbheatliner/eigenschaften/ (access 01.2018)

25. P. Króliczkowski, Nowoczesne Budownictwo Inżynieryjne (2010)

26. http://calorpompyciepla.pl/pl/ (access 01.2018)

27. http://solwar.pl/index.php?id=14\&name=kolektor_gruntowy_poziomy\&lang=pl (access 01.2018)

28. http://www.pompyciepla-podhale.com.pl/realizacje/dimplex_oczyszczalnia, (access 01.2018 )

29. http://wuprinz.pl/realizacje/hermetyzacja-osadnikow-wstepnych-w-centralnejoczyszczalni-sciekw-w-kozieglowach (access 01.2018) 